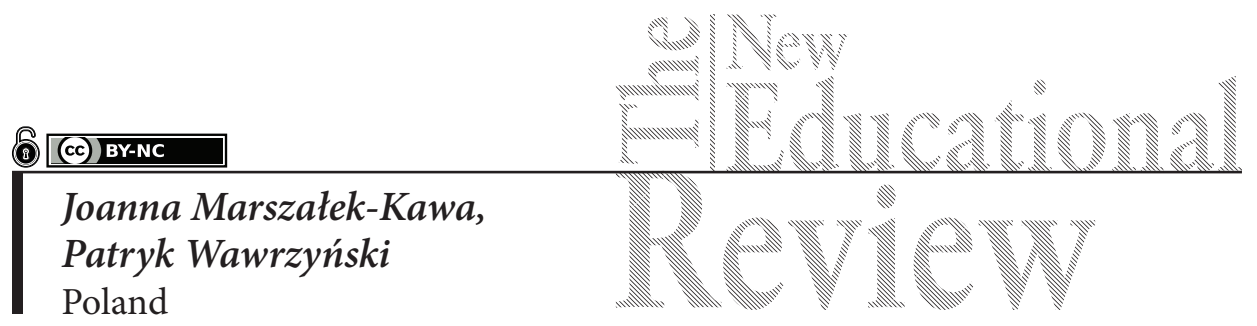

\title{
Promotion of National Heroes as Civic Role-Models during Democratisation
}

DOI: 10.15804/tner.2018.52.2.08

\begin{abstract}
The paper considers the relationship between remembrance narratives on national heroes and proliferation of political attitudes, values and behaviours during democratisation. It discusses the impact of interpretations of the past on the development of civil society in the context of public education as an instrument of identity politics. Comparing the experiences of Chile, Estonia, Georgia, Poland, South Africa and Spain, the authors present the role of national heroes in the legitimisation of behaviours and attitudes, new elites and national unity. The discussed results prove that the establishment of a pro-democratic system of civic education increases chances for successful consolidation of democracy in post-authoritarian countries.
\end{abstract}

Keywords: democratisation, civic society, civic education, national hero, remembrance, narratives

\section{Introduction}

Cicero praised history as a source of knowledge of reality in his famous maxim, historia magistra vitae est. For centuries, philosophers had been promoting this simplified understanding of the political role of the past, until Karl Marx noticed that relations between remembrance and social processes are far more about power and control. However, it was Maurice Halbwachs' (1992) works on collective memory that inspired scholars to discuss the role of remembrance 
narratives as political assets and vibrant sources of shared identities and beliefs. Later, Jan and Aleida Assmann proved that interpretations of past events could serve as carriers for ideas and images, helping to disseminate them within society (Assmann, 2006; 2008; Assmann, 1995; 2011). In fact, now it is clear that history is more than a magistra vitae, as remembrance narratives have become a crucial instrument of social mobilisation or a way in which elites legitimise social order (Westen, 2008, pp. 41-49; Wawrzyński \& Schattkowsky, 2015, p. 74).

The rapid development of memory studies in last decades has shown that interpretations of the past play critical roles in various aspects of social and political life - from identity politics through the distribution of wealth and resources up to the organisation of crimes against humanity. Remembrance delivers explanations and legitimises them in a broader context of historical causation, inevitability and the just world hypothesis (Marszałek-Kawa \& Wawrzyński, 2016, p. 13). Its objective is to inform society about appropriate measures to overcome challenges and protect the imagination of community's 'Ideal Self' (Wawrzyński, 2017, pp. 298-300). It constitutes supporting evidence for opinions and beliefs presenting them as a part of some future-oriented historical process which makes society a better place for its members (Clark, 2018). Finally, remembrance narratives educate citizens and stimulate construction of their conclusions on issues which shape collective identities, political preferences, attitudes and behaviours (Hedtke et al., 2017, p. 11; Offen, 2017).

However, it remains unclear how governments use interpretations of the past to consolidate shared identities and promote social change. Moreover, scholars cannot answer why some memorisations cause dysfunctionalities - perpetuate antagonism and conflicting identities or promote prejudice and national chauvinism (Baliqi, 2018; Żuk, 2018). There are policies which popularise contents critical to the development of civil society: pluralism, democratic values and diversity of perspectives (DesRoches, 2016). There is not enough research evidence concerning the effectiveness of remembrance story-telling to show how governments may adapt their measures to the changing logic and media of social communication, preventing core narratives from fading into oblivion (Brauckmann, 2015, pp. 258-259). In this paper, we consider these aspects of the 'alliance of power and memory' in the context of the promotion of national heroes as civic role-models during democratisation. Therefore, we investigate the role of public education in the construction of post-authoritarian communities of values based on human rights protection, the rule of law, separation of powers and - what is crucial for our study - civic engagement (Agüero, 2007). 
In the $19^{\text {th }}$ century, the public education system became a central instrument of the government's management of collective memory - it has centralised supervision of school standards and curricula since then. It enables political leaders to control all crucial aspects: primary schools, high schools, professional training, universities, adult education and civic education, and consolidate them into one capable device of social influence (Boschki et al., 2015, p. 470). However, as Wolfgang Meseth and Matthias Proske (2015, pp. 177-179) noticed, even this complex machinery might become ineffective if pedagogical communication lacks appropriate strategies to involve the audience and address the problem of contingency. In fact, all the power of the education system is dependent on teachers and public educators, whose competences determine social and political outcomes of remembrance story-telling - if teachers fail, the remembrance policy fails as well (Short, 2015), but if they succeed, history may stimulate society to improve itself (McLaren, 1999).

Public education offers a unique opportunity to present a comprehensive interpretation of history to all citizens, as well as enabling authorities to contextualise it concerning the national identity and promoting the image of the nation's 'Ideal Self'. Its power comes from the completeness of communication. However, it is not limited to it, and as Yuval Dror (2001) states, it helps to construct emotional bonds between citizens and remembrance narratives, moral parallels and individual imaginations of the past. Educators do not merely tell stories; they present narratives as explanations and justifications of institutions, values, symbols of values (Gallant, Hartman, 2001), which is essential for identity reconstruction during political transformations. As a result, story-telling becomes an interactive ritual of commemoration and belonging (Yablonka, 2009).

At the same time, public education still is an instrument of political, indirect and direct, control. Authorities determine its organisation, funding and employment strategy, but they can also influence contents of school curricula and history textbooks. In the second case, curricula and textbooks promote specific definitions and understandings, or - as Alexander Bukh (2007) proved - define the nation's historical sensibility (Thomas, 1993; Storey, 2017; Kennedy, 2017). Therefore, remembrance narratives may mediate proliferation of civic attitudes, values and behaviours, causing some limitation to further democratic development (Komalasari, Saripudin, 2017; Hailat, 2017). They produce boundaries for public debates, defining which actions are either historically appropriate or against the nation's tradition or interests (Fukuoka, 2011). Finally, the public education system can serve as a medium for propaganda and manipulation of public opinion 
- promoted interpretations of the past may legitimise social, economic or political order and refocus citizens from the current state of the nation to unresolved past injustices (Wang, 2008). State-promoted remembrance narratives articulate interests of political elites (Olick, 2007), which can result in both limitation and consolidation of democratic practices. Thus, these decisions are critical for the outcomes of democratisation and its persistence.

\section{Methodology}

The paper presents results of the research project on relationships between the transitional government's remembrance policy and the reconstruction of political identities during post-authoritarian transformations. The study investigated if there is a standard model of remembrance story-telling during democratisation, and how new elites try to use national history to accelerate social, economic and political changes. In general, it considered interpretations of the past as a transitional asset which governments employ to disseminate the new vision of the nation's 'Ideal Self' and transform an authoritarian society into a democratic one (Marszałek-Kawa et al., 2017, pp. 116-117; Ingimundarson, 2007).

The study compared six cases of transitional remembrance policy: Chile, Estonia, Georgia, Poland, South Africa and Spain. We investigated four groups of sources - (1) legislation, policy documents, political strategies and roadmaps, (2) public speeches, interviews and writings of political and social leaders, (3) educational policy statements, school curricula and textbooks, and (4) landscape of memory and museum exhibitions. We used them to analyse relationships between remembrance story-telling and transitional reconstruction of national identity. We grouped all thirty-seven research questions (fields of impact) into eight categories describing the most dense areas of historical justification for: the power of new elites, presence of old elites, transitional justice, social costs of transformations, implementation of new standards, symbolic roles of democratisation, need for national unity and changing position in international politics. In few cases our interest in the transitional 'alliance of power and memory' overlapped with the issue of promotion of national heroes as civic role-models, which we discuss in the paper. We considered reconstruction of the national pantheon as an aspect of new elites' legitimisation (item 1-3), heroes as role-models of democratic attitudes in the context of new political standards (5-3), their role in promotion of new behaviours related to the symbolic role of democratisation (6-4) and new pantheon as realisation of national unity $(7-4)$. 
For all thirty-seven investigated fields of the impact of remembrance on transitional identities, we applied a qualitative-to-quantitative narrative analysis supported by a coding system with five degrees of relevance. Each of them was carefully described, evaluated and rated from the very low to the very high level of significance for the government's policy. As a result, we used descriptive statistics to process collected data and compare selected cases of post-authoritarian transformations. Moreover, it enabled us to discuss the models of political use of remembrance narratives during democratisation and consider the universality of this process.

\section{Results}

In general, the observed role of remembrance narratives in post-authoritarian identity politics was rather moderate, on the edge of the low degree (average: 2.63 points; range: 1-5 points). It was important for the justification of the symbolic roles of democratisation (3.07) and a new identity in international politics (3.00), while rather irrelevant for the explanation of the social costs of transformations (1.83) and transitional justice (2.17). Results for only two categories were correlated with the general shape of remembrance story-telling during the post-authoritarian transition: symbolic roles of change $(r=0.96)$ and its social costs $(r=0.91)$. Three others - identity in international politics, the legitimisation of new elites and previous leadership - were characterised by very week relationships. Using one-way ANOVA, we noticed that significant differences between cases occurred in justifications of transitional justice ( $\mathrm{p}$-value $<0.01$ ), new identity in international politics ( $p$-value $=0.01)$, symbolic roles of democratisation $(p$-value $=0.02)$, new leadership ( $p$-value $=0.03$ ). For the remaining four categories, the observed differences were insignificant.

In our context of national heroes and civic education, the most significant field of impact was the promotion of new behaviours related to the symbolic roles of democratisation (6-4). We ranked it as the fifth of all the investigated items with its average score of 3.5 points. Moreover, its correlation with the general result was one of the strongest observed $(\mathrm{r}=0.75)$, while the results for individual countries were different $(\mathrm{SD}=1.64)$. Reconstruction of the national pantheon to support the power of new elites (1-3) had a moderate influence on transitional remembrance story-telling regarding its average 3 points. The result for heroes as role-models of new democratic attitudes (5-3) was close to the general average, and it was the median of the data sample (2.67 points). Finally, the average score for the new pan- 
theon of heroes as the realisation of national unity (7-4) was significantly lower than in the remaining three discussed issues ( 2.17 points). It was also the least differentiated - the standard deviation equalled 0.75 , while for the other fields of impact it was around two times higher. Besides the first described, these items were not strongly correlated with the general result. However, we observed some significant relationships between them and other items and categories, including the strong correlation between the roles of national heroes in the legitimisation of new elites and democratic attitudes $(r=0.94)$. In general, there were nineteen significant relationships between them and other fields of impact and five with categories (functions of story-telling).

Table 1. The role of national heroes as civic role-models during democratisation

\begin{tabular}{|c|c|c|c|c|c|c|c|c|c|}
\hline Field of impact & $\stackrel{0}{\overparen{Z}}$ & 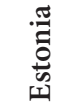 & 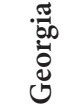 & 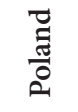 & 吾䒿 & $\begin{array}{l}\text { ज्ञ } \\
\text { के }\end{array}$ & $\mathrm{AM}$ & $\mathbf{r}$ & SD \\
\hline $\begin{array}{l}\text { 1-3: Reconstruction } \\
\text { of the national pantheon }\end{array}$ & 3 & 4 & 2 & 3 & 5 & 1 & 3.00 & 0.44 & 1.41 \\
\hline $\begin{array}{l}5-3 \text { : Heroes as role-mod- } \\
\text { els of democratic attitudes }\end{array}$ & 2 & 4 & 2 & 2 & 5 & 1 & 2.67 & 0.57 & 1.51 \\
\hline $\begin{array}{l}6-4 \text { : Role of heroes in } \\
\text { promotion of new behav- } \\
\text { iours }\end{array}$ & 4 & 4 & 2 & 1 & 5 & 5 & 3.50 & 0.75 & 1.64 \\
\hline $\begin{array}{l}7-4: \text { New pantheon } \\
\text { as the realisation of unity }\end{array}$ & 3 & 3 & 2 & 2 & 2 & 1 & 2.17 & 0.46 & 0.75 \\
\hline Average & 3.00 & 3.75 & 2.00 & 2.00 & 4.25 & 2.00 & 2.83 & 0.76 & \\
\hline
\end{tabular}

Source: based on calculations discussed in Marszałek-Kawa et al., 2017 (AM - arithmetic mean, $\mathrm{r}$ - Pearson correlation coefficient, SD - standard deviation; scores of fields of impact: 1 - very low role in transitional identity reconstruction, 2 - low, 3 - moderate, 4 - high, 5 - very high).

Therefore, we investigated four aspects of using national heroes in transitional identity politics, regarding new elites, political attitudes and behaviours or a need for unity. The average result for these fields was approximately $7.5 \%$ higher than the general average, and there was some apparent relationship between the results $(\mathrm{r}=0.76)$. Further, in the established simplified model MTR19 of nineteen most relevant items (Marszałek-Kawa et al., 2017, pp. 163-167) we excluded only the role of new pantheon as the realisation of national unity. The average for national heroes as civic role-models was still about $7.5 \%$ higher than the general average (3.06 points to 2.84$)$, but the correlation became even stronger $(r=0.85)$, which 
proves that narratives on national heroes have a profound influence on transitional remembrance story-telling.

\section{Conclusion}

Democratisation forces society to evaluate its political identity critically. Post-authoritarian conditions promote the establishment of the nation's new 'Ideal Self'. One of the core means of its proliferation are interpretations of the past. Moreover, remembrance story-telling seems to regulate emotional responses to transformations, and it explains changes as a predictable process (Marszałek-Kawa et al., 2017, pp. 169-171; Marszałek-Kawa, Wawrzyński, 2016, pp. 19-20). History becomes a political asset that can be used in the process of society's reconstruction or deconstruction of cultural patterns (Wawrzyński, Stańco-Wawrzyńska, 2016, p. 146). It is visible in the discussed context of national heroes and civic education.

Collected data showed that the significant transitional objective was to promote democratic behaviours thanks to compelling role-models. Their importance increased when the reconstruction of society and reconciliation were presented as aims of transformations (Chile, Estonia, South Africa and Spain). On the other hand, in countries like Poland, where governments limited their involvement in remembrance story-telling and identity politics, the emerging civil society was left without promoted democratic role-models. It might be an explanation why some post-authoritarian societies experience backslides in the consolidation of democracy because there are no established links between essential historical narratives and democratic 'codes of conduct' (Hall, 2018). For all societies, public education seems to be a critical area for this process (Schuitema et al., 2017). Yet, as we found in our study, some governments tend to underestimate it and focus mostly on legal and economic affairs.

We observed that national heroes are an essential instrument of the legitimisation of new elites, and this aim manifests itself in education policies. There are at least two types of historical justification. Firstly, heroes of the pro-democratic movement become role-models of civic behaviours and new school curricula protect their central position in the national pantheon. Secondly, the government incorporates other mainstream heroes into legitimising narratives to prove that new elites have full authority to govern the state. The South African case is a good example - during Nelson R. Mandela's presidency, the African National Congress centralised remembrance narratives around itself despite the indignation of other anti-apartheid organisations. 
Both aspects influence the way in which national heroes promote democratic attitudes. Even if our study showed that governments express rather low interest in them, in countries like Estonia and South Africa remembrance narratives were a key instrument in the popularisation of civic engagement, activism, tolerance or reconciliation. However, as Nadine Sika (2016) proved, it might be the highly underrated aspect of democratisation where public education plays a critical role in the transformation of society. Finally, as in the case of Chile, reconstruction of the national pantheon may represent a political dream of national unity and inclusive community, despite its moderate role in transitional identity politics. Therefore, it should be present in divided or diverse societies (Baba, Aeysinghe, 2017, p. 47).

The results of our investigations prove that use of national heroes as democratic role-models is essential for civic education during transformation. We observed their significant position in the complex of remembrance narratives, especially if the government set reconstruction of society as a transitional objective. Also, we noticed that public education played a crucial role in the proliferation of historical interpretations associated with civic role-models. Considering the collected data, we believe that without the establishment of a pro-democratic system of education it is almost impossible to prevent backslides in the consolidation of democracy and classrooms are as essential areas of democratisations as public offices, courthouses, newsrooms or enterprises.

\section{Acknowledgments:}

The paper is a result of the research project Politics of Memory as the Constitutional Factor of New Identities during the Transition from Authoritarian Regimes financed from the funds of the National Science Centre in Kraków, Poland, by the decision no. DEC-2012/05/E/ HS5/02722.

\section{References:}

Agüero, F. (2007). Dictatorship and Human Rights: Politics of Memory. Radical History Review, 97, pp. 123-133.

Assmann, A. (2006). Memory, Individual and Collective. In R.E. Goodin, C. Tilly (eds.), The Oxford Handbook for Contextual Political Analysis (pp. 210-224). Oxford-New York: Oxford University Press.

Assmann, A. (2008). Transformations between History and Memory. Social Research: An International Quarterly, 75(1), pp. 49-72. 
Assmann, J. (1995). Collective Memory and Cultural Identity. New German Critique, 68, pp. $125-133$.

Assmann, J. (2011). Cultural Memory and Early Civilization: Writing, Remembrance, and Political Imagination. New York: Cambridge University Press.

Baba, I., Aeysinghe, C. (2017). Re-Positioning Nigeria towards Sustainable National Unity. Global Journal of Human Social Science Research, 17(4-H), pp. 41-49.

Baliqi, B. (2018). Contested war remembrance and ethnopolitical identities in Kosovo. Nationalities Papers, 46(3), pp. 471-438. DOI: doi.org/10.1080/00905992.2017.1375906.

Boschki, R., Reichmann, B., Schwendemann, W. (2015) Towards a New Theory of Holocaust Remembrance in Germany: Education, Preventing Antisemitism, and Advancing Human Rights. In Z. Gross, E. Stevick (eds.), As the Witnesses Fall Silent: $21^{\text {st }}$ Century Holocaust Education in Curriculum, Policy and Practice (pp. 469-488). Cham-Heidelberg-New York: Springer.

Brauckmann, S. (2015). "How Do You Wish to Remember?" - Youth Participation and Culture of Remembrance Using Geo-Information. GI Forum - Journal for Geographic Information Science, 1, pp. 251-260.

Bukh, A. (2007). Japan's History Textbooks Debate: National Identity in Narratives of Victimhood and Victimization. Asian Survey, 47(5), pp. 683-704.

Clark, P. (2018). Rwanda's Recovery: When Remembrance Is Official Policy. Foreign Affairs, 97(1), pp. 35-41.

Cohen, G.A. (1978). Karl Marx's Theory of History. Princeton: Princeton University Press.

DesRoches, S.J. (2016). Remembering Otherwise: History and Citizenship Education of Shared Fates. Philosophy of Education Yearbook, 2016, pp. 582-592.

Dror, Y. (2001). Holocaust Curricula in Israeli Secondary Schools, 1960s-1990s: Historical Evaluation from Moral Education Perspective. Journal of Holocaust Education, 10(2), pp. 29-39.

Fukuoka, K. (2011). School History Textbooks and Historical Memories in Japan: A Study of Reception. International Journal of Politics, Culture, and Society, 24, pp. 83-103.

Gallant, M.J., Hartman, H. (2001). Holocaust Education for the New Millennium: Assessing our Progress. Journal of Holocaust Studies, 10(2), pp. 1-28.

Hailat, S. (2017). The Image of Women in the Books of National and Civic Education of Basic Stage in Jordan. The New Educational Review, 49(3), pp. 115-125. DOI: dx.doi. org/10.15804/tner.2017.49.3.09.

Halbwachs, M. (1992). On collective memory. Chicago: The University of Chicago Press.

Hall, E. (2018). Integrity in democratic politics. British Journal of Politics and International Relations, 20(2), pp. 395-408. DOI: doi.org/10.1177/1369148117744956.

Hedtke, R., Proeschel, C., Szukala, A. (2017). The Transformation of Civic and Citizenship Education: Challenges to Educational Governance, Agency and Research. An Introduction. Journal of Social Science Education, 16(4), pp. 110-121. DOI: dx.doi.org/10.4119/ UNIBI/jsse-v16-i4-1785.

Ingimundarson, V. (2007). The Politics of Memory and the Reconstruction of Albanian National Identity in Post-war Kosovo. History \& Memory, 19(1), pp. 95-123. 
Kennedy, D. (2017). Anarchism, Schooling, and Democratic Sensibility. Studies in Philosophy and Education, 36(5), pp. 551-568. DOI: doi.org/10.1007/s11217-016-9534-3.

Komalasari, K., Saripudin, D. (2017). A Model of Living Values Education-Based Civic Education Textbooks in Indonesia. The New Educational Review, 47(1), pp. 139-150. DOI: doi.org/10.15804/tner.2017.47.1.11.

Marszałek-Kawa, J., Wawrzyński, P. (2016). Remembrance, Identity Politics and Political Transitions: A Comparative Study. Polish Political Science Yearbook, 45, pp. 11-21. DOI: doi.org/10.15804/ppsy2016001.

Marszałek-Kawa, J., Wawrzyński, P., \& Ratke-Majewska, A. (2017). The Politics of Memory in Post-Authoritarian Transitions, Volume Two: Comparative Analysis. Newcastle: Cambridge Scholars Publishing.

McLaren, P. (1999). Research news and Comment: A Pedagogy of Possibility: Reflecting Upon Paulo Freire's Politics of Education. Educational Researcher, 28(2), pp. 49-56. DOI: doi.org/10.3102/0013189X028002049.

Meseth, W., Proske, M. (2015). Mind the Gap: Holocaust Education in Germany, between Pedagogical Intentions and Classroom Interactions. In Z. Gross, E. Stevick (eds.), As the Witnesses Fall Silent: $21^{\text {st }}$ Century Holocaust Education in Curriculum, Policy and Practice (pp. 159-182). Cham-Heidelberg-New York: Springer.

Offen, S. (2017). 'Places of Remembrance': Spaces for Historical and Political Literacy. A Lesson Report. Journal of Social Science Education, 16(4), pp. 2-15. DOI: dx.doi. org/10.4119/UNIBI/jsse-v16-i4-1642.

Olick, J.K. (2007). The politics of regret: On collective memory and historical responsibility. New York: Routledge.

Schuitema, J., Radstake, H., van de Pol, J., Veugelers, W. (2017). Guiding classroom discussions for democratic citizenship education. Educational Studies. DOI: doi.org/10.1 080/03055698.2017.1373629.

Short, G. (2015). Failing to Learn from the Holocaust. In Z. Gross, E. Stevick (eds.), As the Witnesses Fall Silent: $21^{\text {st }}$ Century Holocaust Education in Curriculum, Policy and Practice (pp. 455-468). Cham-Heidelberg-New York: Springer.

Sika, N. (2016). Ambiguities of student activism, authoritarianism and democratic attitudes: the cases of Egypt and Morocco. The Journal of North African Studies, 22(1), pp. 35-59. DOI: doi.org/10.1080/13629387.2016.1229183.

Storey, I. (2017). The Politics of Defining Today: Towards a Critical Historicism of Judgment. Arendt Studies, 1, pp. 61-86. DOI: doi.org/10.5840/arendtstudies2017957.

Thomas, J. (1993). Citizenship and historical sensibility. Australian Historical Studies, 25(100), pp. 383-393. DOI: doi.org/10.1080/10314619308595920.

Wang, Z. (2008). National Humiliation, History Education, and the Politics of Historical Memory: Patriotic Education Campaign in China. International Studies Quarterly, 52, pp. $783-806$.

Wawrzyński, P. (2017). The Government's Remembrance Policy: Five Theoretical Hypotheses. Polish Political Science Yearbook, 46(1), pp. 294-312. DOI: doi.org/10.15804/ ppsy2017119 
Wawrzyński, P., Schattkowsky, R. (2015). Attitudes towards the government's remembrance policy in Poland: results from an experimental study. Politics in Central Europe, 11(2), pp. 73-94. DOI: doi.org/10.1515/pce-2015-0012.

Wawrzyński, P., Stańco-Wawrzyńska, A. (2016). South African Post-Apartheid Transitional Remembrance Policy (1994-1999). Polish Political Science Yearbook, 45, pp. 145-154. DOI: doi.org/10.15804/ppsy2016011.

Westen, D. (2008). The Political Brain. The role of emotion in deciding the fate of the Nation. New York: Public Affairs.

Yablonka, H. (2009). Izraelczycy i Szoah: pamięć, tożsamość i dyskurs. In E. Kossewska (ed.), Brzemię pamięci. Współczesne stosunki polsko-izraelskie (pp. 95-112). Warszawa: Wydawnictwo Neriton.

Żuk, P. (2018). Nation, national remembrance, and education - Polish schools as factories of nationalism and prejudice. Nationalities Papers. DOI: doi.org/10.1080/00905992.20 17.1381079. 